\title{
RACE, SOVEREIGNTY, AND CIVIL RIGHTS: Understanding the Cherokee Freedmen Controversy
}

\author{
CIRCE STURM \\ University of Texas at Austin
}

They spoke Cherokee, lived among Cherokees, and shared Cherokee ways of life, yet they and their descendants have rarely been accepted as legitimate Cherokee people. This is the long-standing situation of the Cherokee Freedmen, the descendants of African Cherokee slaves once held by Cherokee slave owners. ${ }^{1}$ Despite a treaty in 1866 between the Cherokee Nation and the U.S. government granting them full tribal citizenship (Treaty with the Cherokee, 1866, 14 Stat. 799), Cherokee Freedmen continue to be one of the most marginalized communities within Native North America. In a series of court cases during the past 150 years, Cherokee Freedmen in Oklahoma have sought full tribal citizenship within the Cherokee Nation, something they believe is their legal and moral right. These rights have been denied for many reasons, often because most Freedmen lack a Certificate Degree of Indian Blood (CDIB) and are assumed, as a class, to have no lineal blood ties to the Cherokee Nation. ${ }^{2}$ Yet in fact many Freedmen with Cherokee ancestry cannot obtain a CDIB because they descend from black Cherokees who were racially misclassified on a tribal census known as the Dawes Rolls, created at the turn of the twentieth century for the purpose of land allotment. At that time, most African Cherokee individuals were placed on the Freedmen rolls of the Cherokee census, which are now interpreted as the "Black" or non-Indian rolls, rather than the "Cherokee by Blood" rolls. 
Whether or not they have Cherokee ancestry, Cherokee Freedmen have encountered intense opposition whenever they have sought the full rights and benefits given other tribal citizens. That opposition has usually played out in federal and tribal courts. More recently, however, in 2006 and 2007, opposition to Freedmen recognition took place on a wider scale than ever before: in public speeches, grassroots petitions, e-mail campaigns, and letters to the editor in the tribal newspaper. Cherokee citizens in Oklahoma publicly debated the status of Cherokee Freedmen because their principal chief, Chadwick Smith, had called for an unprecedented special election to change tribal citizenship requirements. The proposed change would amend the Cherokee constitution to specify that all Cherokee citizens had to descend from ancestors listed on the Dawes Rolls as Cherokees by blood. Because the Freedmen were enrolled in a separate category - on what amounted to a black citizen roll that did not specify any Cherokee blood quantum — the amendment would effectively deny the Cherokee Freedmen a place in the tribe once and for all.

The political controversy surrounding the special election provides an excellent case study for exploring the intersections of race and sovereignty. The ongoing story of the Cherokee Freedmen's struggle for political recognition reveals the tensions between two competing sets of rights claims - civil rights versus tribal sovereignty - that are often in conflict in Indian Country in ways not yet fully explored. While civil rights apply to everyone equally and are understood to be largely about individual equality and full incorporation into the nation-state, tribal sovereignty concerns collective rights and some degree of political autonomy from the nation-state. Civil rights are also explicitly imagined as an antidote to racial discrimination, whereas sovereign rights are associated less with race and racism and more with the unique political status of indigenous peoples as citizens of domestic dependent nations. In fact, the uniqueness of the indigenous position is often foregrounded within Native American studies, where the rallying cry has long been "American Indian tribes are nations, not minorities" (Wilkins 2001, 33). The same holds true for federal Indian law, where "American Indian" has been repeatedly upheld as an explicitly political rather than racial category (see Rolnick 2011 on Morton v. Mancari 417 U.S. 535 [1974]; and Strong 2005 on The Indian Child Welfare Act, 25 U.S.C. § 1901-1963 [1978]).

This insistence on Indian as a political category is understandable given that, as the Chickasaw literary scholar Jodi Byrd (2011, 34) has so astutely argued, creating "Indian" as a racial identity out of more than five hundred nations is a process of minoritization under settler colonialism that makes racial what is in 
fact international. Furthermore, when we try to understand contemporary indigenous politics in the United States using standard tropes of racial struggle, we can find them insufficient and even distorting. As the Native Hawaiian scholar J. Kehaulani Kauanui $(2008$, 636, 641-42) points out, not only do indigenous people have radically different goals than those that emerge from the project of civil rights but "issues of indigenous politics are inadequately addressed by either civil rights discourse or pluralist discourses of inclusion, even while they are misconstrued as [being] race based." Yet while the lens of racial struggle, and more specifically of civil rights, can obscure our understanding of indigenous political processes, so too can insisting that the exercise of tribal sovereignty is a strictly political process without significant racial dimensions. In this article, I want to put the racial and the political back together again, because that is in fact how they function in the world, to explore how racial dynamics can both empower and undermine tribal sovereignty. My hope is that with careful ethnographic attention to the diverse articulations of race and sovereignty occurring in the Cherokee Nation between 2006 and 2007, we might rethink some of the lingering effects of settler colonialism as a political project. $^{3}$

\section{BLOOD MEASURES: The Origins of the Special Election Controversy}

The origins of the special election controversy go back to 1983. That year, the Cherokee Tribal Council annotated the Cherokee National Code to specify that "tribal membership is derived only through proof of Cherokee blood based on the Final Rolls" (11 CNCA $\S 12)$. For the past three decades, the descendants of Cherokee Freedmen have argued in cases before federal and tribal courts that this decision violates not only the Treaty of 1866 but also the Cherokee Nation's own constitution, and that this relatively new blood requirement places an undue burden on Freedmen descendants. Even those with proof of Cherokee ancestry in other documents cannot satisfy the requirements for tribal citizenship because their relatives were racially misclassified on the Dawes Rolls in the first placemeaning they were placed on the Freedmen rolls, rather than on the Cherokee by Blood rolls. Yet the decisions reached in nearly every case before the federal courts asserted that U.S. courts have no jurisdiction over the Cherokee Freedmen's citizenship status because it constitutes an internal tribal dispute and thus a matter of tribal sovereignty. The principle of sovereignty, as understood in U.S. federal Indian law, means that only the Cherokee Nation and its people can determine its own citizenry. Although the Freedmen have argued repeatedly that 
racial bias prevents them from getting a fair hearing in the tribal courts, the federal courts have consistently upheld the principle of tribal sovereignty as something that trumps the Freedmen's call for civil rights.

When the Freedmen did eventually turn from the federal to the tribal courts in the 1998 case of Bernice Riggs, racial bias seemed to influence the final decision. Using tribal and federal documents, Riggs traced her lineage to a Cherokee forebear who had served in the Indian Home Guard during the Civil War-evidence that the Cherokee court acknowledged as valid proof of Cherokee ancestry. Yet because her Cherokee ancestor had died before the completion of the Dawes enrollment process, his descendants were listed on the Freedmen rolls rather than on the Cherokee by Blood rolls. As a result, Riggs did not qualify for tribal citizenship. The court made no allowance for the fact that Dawes applicants with Cherokee and white ancestry would not have faced the same potential for racial misclassification and ensuing loss of political standing. In the end, not only did the Cherokee Judicial Appeals Tribunal (JAT), now known as the Cherokee Nation Supreme Court, delay the Riggs decision for nearly three years but it upheld business as usual, stating that Freedmen appeals for citizenship constituted a special class and would have to be heard on a case-by-case basis (Riggs v. Ummerteskee, JAT-97-03). Riggs was denied Cherokee citizenship in the name of tribal sovereignty, and the long-awaited decision was in fact no decision at all, as it left unresolved the question of the Freedmen's collective rights to tribal citizenship.

A turning point came in September 2004, when David Cornsilk, a Cherokee citizen and lay lawyer, filed another lawsuit in the Cherokee courts on behalf of Lucy Allen, a Cherokee Freedmen descendant (Allen v. Cherokee Nation Tribal Council, et al., JAT-04-09). The facts of the case closely resembled those presented by Riggs. Allen had both African and Indian forebears. Some of her ancestors had been listed on the Cherokee Freedmen Rolls, while others had been recorded as Cherokee Indians on earlier tribal rolls, but none of them appeared on the Dawes Cherokee by Blood rolls. Although Allen could prove that she had both Cherokee Freedmen and Cherokee Indian ancestry, she still remained ineligible for Cherokee citizenship, again because of the new Cherokee blood requirement spelled out in section 12 of the Cherokee National Code (11 CNCA $\S 12$ ). The arguments in Allen differed slightly from those presented in Riggs in that they focused less on the bureaucratic erasure entailed in the Dawes enrollment process and more on the illegality of the amended code according to the Cherokee Nation's own law. This latter point - that section 12 violated the Cherokee Nation's own con- 
stitution - proved the most decisive factor in changing the opinion of the Cherokee court.

Shortly after the Allen case was heard, political turmoil erupted in the Cherokee Nation that impacted all branches of tribal government; thus the court did not reach a decision regarding the case for another two years (Sturm 2011, 147-48). Eventually, on March 7, 2006, the Cherokee Nation Supreme Court determined that section 12 of the Cherokee National Code was indeed unconstitutional. The majority opinion, written by Justice Stacy L. Leeds, stated that according to the 1975 Cherokee constitution, "All members of the Cherokee Nation must be citizens as proven by reference to the Dawes Commission Rolls. ... There is simply no 'by blood' requirement in Article III. There is no ambiguity to resolve. The words 'by blood' or 'Cherokee by blood' do not appear" (JAT04-09, 13, 3). Leeds clarified that what mattered in determining eligibility for tribal citizenship was lineal descent from relatives politically associated with the Cherokee Nation and recognized as its citizens - whether they were white, black, Cherokee, or other adopted Indians. She went on to assert that because the Freedmen were enumerated as citizens of the Cherokee Nation on the Dawes Rolls, they were also expressly included as citizens under the 1975 constitution, and thus continued to have rights of citizenship at present (JAT-04-09, 13).

This momentous decision was cause for great celebration among descendants of the Cherokee Freedmen, and the tribal registrar quickly moved in the spring of 2006 to create a new registration form for Freedmen applicants, one with no CDIB requirement. Other quarters of the Cherokee Nation showed a less jubilant mood. Some tribal citizens and political leaders immediately began questioning the Cherokee Ccourt's decision, believing that even if the tribal constitution had not specified an ancestry requirement for citizenship, kinship was the fundamental glue holding together Cherokee society. For them, Cherokee blood constituted a critical measure of tribal belonging, and they assumed that Cherokee Freedmen had no kinship ties with Cherokee people. However, only a week after the ruling, Principal Chief Chad Smith raised another, more inflammatory set of concerns. On March 13, 2006, he addressed the Tribal Council, stating that citizenship was an important matter of sovereignty that should be determined by the Cherokee people themselves. He went on to say that many Cherokee citizens disagreed with the court's decision because they believed the Freedmen had done nothing for the tribe in the past one hundred years and that their ancestors had received compensation through the receipt of allotments as slave reparations, unlike freed slaves in the southern United States (Smith 2006; Vann 2006a). 
By interjecting the idea of slave reparations into the contemporary Cherokee Freedmen controversy, Smith attempted to draw a political and racial distinction between Cherokees and Cherokee Freedmen descendants that does not exist, at least not as he has suggested. Under the General Allotment Act of 1887, also known as the Dawes Act, all Cherokee citizens received individual parcels of land, whether they were enumerated on the Dawes Rolls as Cherokees by Blood, as "Intermarried Whites," or as Freedmen. Although there were differences in the size and location of the allotments, as well as in the restrictions placed on them, they were distributed to all citizens of the Cherokee Nation equally. Thus allotments were not a means by which the Cherokee Nation compensated the previously enslaved for their labor, but rather a way in which the nation acknowledged the Freedmen as a class of citizens with a legitimate share in tribal holdings. The argument that the Freedmen were paid off is not Chief Smith's unique vision but is one of several that exacerbate tensions over race and class in the Cherokee Nation, for it portrays Freedmen descendants as a group for whom economic greed motivates their desire for political recognition.

Whether during the controversy the arguments against Freedmen inclusion focused on blood kinship, economic greed, or some other factor, they were frequently articulated in the name of a racialized national sovereignty. In fact, from March 2006 forward, Smith went from town to town in northeastern Oklahoma, pressing for a vote on the Freedmen's citizenship rights and hoping to secure a constitutional amendment that would define the Cherokee Nation in terms of "blood" (as a proxy for both race and kinship) for the first time. Freedmen opponents like Chief Smith had two options: the question of blood-based citizenship could be placed on the next general election ballot by the Tribal Council or by citizens petitioning for a referendum. A few months later, during its regularly scheduled June 2006 meeting, a majority of the Tribal Council voted to place the citizenship question before the Cherokee people as a constitutional amendment. The vote was scheduled to take place during the next tribal elections to be held a year later in June 2007, but some Cherokee citizens expressed dissatisfaction with having to wait that long. Instead, they began a petition drive calling for an unprecedented special election. According to the newly revised Cherokee constitution (2003), Cherokee citizens can petition to amend their constitution with the support of at least fifteen percent of registered voters. Because there are far fewer registered voters than the nearly 270,000 tribal citizens, the petition was approved on the basis of only 2,100 signatures. As a result, the Cherokee Nation scheduled a special election to decide the Freedmen's fate on March 3, 2007. 
Several former tribal officials, including former Deputy Chief John Ketcher, who had served under Principal Chief Wilma Mankiller, became the driving force behind the call for a constitutional amendment. In the months preceding the special election, arguments over Cherokee citizenship, nationalism, and identity were often framed in terms of race, rather than ancestry, at least among those supporting the amendment. A key idea behind the push for change was that Cherokees had a right to define themselves in explicitly racial terms as an Indian nation, even in the face of a far more complex historical reality. I quote at length from a paid advertisement in the February 2007 edition of the tribal newspaper the Cherokee Phoenix, because it represents these types of arguments. The advertisement, in which Ketcher addressed Cherokee citizens, urged Cherokees to vote in favor of the amendment:

\section{March 3 you will vote on who can be members of the Cherokee Nation.}

Voting YES means that only Indians will be members of the Cherokee Nation. This includes the Cherokees by blood, Cherokee Shawnees and Cherokee Delawares.

Voting NO means that non-Indians including Freedmen (former slaves and non-Indians of African descent) and Inter-married Whites will be members of the Cherokee Nation.

\section{WHO ARE THE FREEDMEN?}

According to the Dawes Commission and federal law they are former slaves of Cherokees and non-Indians of African descent. In 1906, the Dawes Commission created rolls for Freedmen and Inter-married Whites, Cherokees by blood, Cherokee Shawnees by blood and Cherokee Delawares by blood. The Dawes Commission determined Freedmen and Inter-married Whites had no Indian blood. Freedmen are not "Black Indians" otherwise they would be listed on the Dawes Roll as Cherokee by blood.

\section{WHAT DOES IT MEAN IF I VOTE YES ON THE AMENDMENT?}

It means you have to have an Indian ancestor on the Dawes Roll to be a member of the Cherokee Nation. It means the Cherokee Nation will be an Indian tribe made up of Indians. The Dawes roll is the base roll for Cherokee 
membership. It will mean non-Indians such as Freedmen and Inter-married Whites will not be members.

\section{WHAT DOES IT MEAN IF I VOTE NO ON THE AMENDMENT?}

It means approximately 40,000 non-Indian Freedmen and Inter-married Whites will be eligible for Cherokee Nation membership and entitled to all the services and benefits Cherokees received today. It means these 40,000 non-Indians will be eligible to use the Indian hospitals and clinics, receive housing and education scholarships and Indian preference in contracting and employment. (Ketcher 2007, 20; emphasis in the original)

As seen in this advertisement, the call for new citizenship requirements reflects a more explicitly racialized tribal nationalism, especially if we consider the fact that throughout much of its history, the Cherokee Nation has been a racially and ethnically plural society, incorporating other tribes (such as the Loyal Shawnee and Delaware), other individual Indians (including Natchez and Catawba people), African American Freedmen, African Cherokee Freedmen, and intermarried whites. To protect racial distinctiveness as a national property is the only reason why the citizenship amendment would explicitly include other Indians, meaning the Loyal Shawnee and Delaware, but not intermarried whites and Cherokee Freedmen. Instead, the discourse repeatedly cast the latter two groups as nonIndians (Cherokee Nation 2007a). ${ }^{4}$

To further challenge the case of the Cherokee Freedmen, supporters of the constitutional amendment also played on anti-black sentiments among some sectors of the Cherokee population, ones that, again, equated blackness with economic opportunism. In the same paid advertisement, Ketcher (2007, 20) explained the reason why the Cherokee Freedmen desired inclusion in the Cherokee Nation: "Their leader told them they would get benefits and services such as using the Indian hospital and clinics, educational scholarships, housing, social services, preference in employment and contracting, voting in elections and holding Cherokee Nation office." He then summarized why Cherokees should vote in favor of the amendment:

When a group of non-Indians wants to be Cherokees, not having a drop of Cherokee blood, and take away the few benefits that are left it is an issue of “enough is enough.” Many Cherokees don't want non-Indians claiming to be Cherokee. Many Cherokees don't want to stand in longer lines for services from the Cherokee Nation. Many Cherokees don't want to have to 
wait longer at the Indian hospital because of 40,000 non-Indians using these health facilities. Many Cherokees want the Cherokee Nation to be an Indian tribe made up of Indians just like every other tribe in the United States.

Ketcher's rhetoric implied that allowing the Cherokee Freedmen to remain citizens would result in a flood of opportunistic non-Indian enrollments quickly transforming the Cherokee Nation into a welfare state.

Echoing the anti-Freedmen rhetoric of the Ketcher advertisement, Darren Buzzard, a Cherokee Nation employee, wrote an even more disturbing letter to the Cherokee councilwoman Linda O'Leary that also circulated widely during the weeks preceding the special election. "Don't get taken advantage of by these people," he warned of the Freedmen. "They will suck you dry." He went on to write, "Don't let black freedmen back you into a corner. PROTECT CHEROKEE CULTURE FOR OUR CHILDREN. FOR OUR DAUGHTER[S] . . . FIGHT AGAINST THE INFILTRATION" (Knickmeyer 2007; emphasis in the original). Not only was Buzzard labeling the Freedmen as black to associate them with racial stereotypes about welfare and aggression but he also raised the specter of black Indian miscegenation as a threat to Cherokee women's virtue - a sentiment that seemed to come straight from the Jim Crow South. His fear of miscegenation evokes not only a concern about interracial sex but also, by extension, about the potential for black Indian offspring to compromise the racial integrity of the Cherokee Nation.

This concern with racial integrity and Indian identity appears ironic, given the Cherokee Nation's long history of racial inclusiveness and its current enrollment policies requiring proof of lineal descent from a Dawes enrollee, rather than a specific Cherokee Indian blood quantum. Because no minimal degree of ancestry is required, current tribal citizens have CDIBs that range from "fullblood" Cherokee ancestry to "1/4096," a fact well known and sometimes controversial in Indian Country. Cherokee citizens are extremely diverse, and one would assume that the tribe's policy of lineal descent is meant to measure kinship and historical political association rather than racial identity. Yet that same policy also introduces some racial insecurity. Many Cherokees do conflate ancestry with race, partially because of their awareness that the broader public racializes their status as an indigenous nation. So, another concern is that the appearance of racial dilution may threaten their political recognition and eventually their sovereignty. For many Cherokee, the logic of hypodescent, or the so-called one-drop rule, that overdetermines the social and racial classification of African descendants in 
the United States, creates a situation in which Cherokee Freedmen citizens threaten the Cherokee Nation's status as a tribe of Indians more than do Cherokeewhite descendants or any other admixtures. Ironically, the same holds true even in cases where Cherokee Freedmen have greater degrees of Cherokee blood than other segments of the tribal population.

Not surprisingly, this highly racialized discourse outraged the Cherokee Freedmen, and they responded with their own information campaign. They argued that casting Cherokee national identity strictly in terms of blood or race ignored all other forms of Cherokee social and political belonging that had previously constituted Cherokee citizenship in the nation's long history. They pointed to the ways in which Freedmen had participated in the civic and social life of the Cherokee Nation, even as it seemed to grow increasingly hostile to their inclusion. As evidence, they named six Cherokee Freedmen leaders who had served on the Cherokee National Council: Joseph Brown in 1875, Frank Vann in 1887, Jerry Alberty in 1889, Stick Ross in 1893, and both Ned Irons and Samuel Stidham in 1895 (Vann 2006a). They described how they had continued to reside within the Cherokee Nation proper, primarily in its original Illinois, Muskogee, Tahlequah, and Cooweescoowee districts, the same areas in which Freedmen had once held elected political office, and how they had continued to participate in the newly reformed Cherokee national government in the early 1970s, even though few benefits were then available to citizens with less than one-quarter of Cherokee blood (Feldhousen-Giles 2007, 189-90).

They went on to describe other forms of civic engagement, beyond formal political participation, some of which seem surprising given that anti-black racism in the twentieth century would likely compel Freedmen descendants into identifying themselves as black, rather than Cherokee. Resisting that kind of hegemonic thinking, the Freedmen continued to identify themselves in more complex ways. By their own accounts, they did so by continuing to speak Cherokee and holding Cherokee-language church services in primarily Cherokee Freedmen congregations (Knickmeyer 2007). Some of those who did not speak the language attended Cherokee language classes alongside other Cherokee citizens. Others joined the Cherokee Historical Society, taught at local Indian schools, and worked for the Bureau of Indian Affairs (BIA), while still others worked at the local Indian Hospital as nurses and orderlies. Another group of Freedmen helped build the Cherokee community building in South Coffeyville, and until about forty years ago, when its fire was extinguished, Freedman even had their own ceremonial ground in Nowata County (Vann 2006b). All these examples served as a direct 
counter to the chief's claim that Freedmen had disappeared from Cherokee civic life in the past century. When they knew their rights to tribal citizenship were on the line, Freedmen fought hard to challenge the negative discourse circulating in the press and in private conversations. Despite their efforts, they did not manage to stop the special election that would give Cherokee citizens a stark choice between including and excluding several thousand individuals.

\section{THE SPECIAL ELECTION AND ITS REPERCUSSIONS}

Amid rather contentious debates the polls for the special election opened on March 3, 2007. Maybe the wintry weather kept people at home, or maybe it was some trepidation among Cherokee voters who acknowledged the importance of citizenship to tribal sovereignty but who were put off by the apparent racial politics at play. Either way, voter turnout remained fairly low for such a significant issue. Whereas nearly forty percent of registered voters had participated in the previous general election, less than a quarter did so in this one (Russell 2011). This spelled bad news for the Freedmen and their allies in the Cherokee Nation. Of the 8,743 voters who did participate in the election, an overwhelming majority (seventy-six percent) favored changing tribal citizenship requirements. As a result, the previous decision of the Cherokee Nation Supreme Court to recognize the ongoing rights of Cherokee Freedmen to tribal citizenship, a decision based on Cherokee legal precedent and Cherokee constitutional law, had now been undone.

Despite their disappointment about the election's outcome, the Freedmen immediately rallied. They held protests at the Bureau of Indian Affairs in Muskogee and at the state capitol in Oklahoma City (Ruckman 2007). Some 250 of them also filed a temporary injunction in the District Court of the Cherokee Nation, asking that their citizenship be reinstated so they could vote in the upcoming general election (Nash, et al., vs. Cherokee Nation Registrar, No. CV-0740). This time the Freedmen had better luck. On May 17, 2007, only six weeks before the election, John Cripps, a Cherokee Nation District Court judge, temporarily reinstated the Cherokee Freedmen to citizenship until the court could reach a decision regarding the merits of their case. Significantly, the injunction meant that despite efforts to remove about twenty-eight hundred Freedmen from political standing, they could still vote in the upcoming tribal election. This decision did not bode well for Chief Chad Smith, who was running for reelection against Stacy Leeds, the former Cherokee Nation Supreme Court justice who had written the majority opinion in favor of the Freedmen in March 2006. Because 
the current chief had repeatedly lobbied against Freedmen inclusion, his challenger could expect their support at the polls. Even though their numbers were relatively small in comparison to the overall Cherokee population, the Freedmen could still sway an election, particularly if they voted as a block.

Ironically, the Freedmen's historic track record of actively participating in Cherokee national elections may have worked against them, as they may have been perceived as a political threat that could be more easily nullified in the courts than at the ballot box. In discussions about why there had been a petition drive for a special election in the first place, many Freedmen descendants and their supporters believed that it was primarily an effort to disenfranchise them before they could vote against the incumbent chief. Some Freedmen claimed that history was repeating itself, an allusion to the 1983 election for principal and deputy chief, when incumbents Ross Swimmer and Wilma Mankiller ran on a ticket against Perry Wheeler and Agnes Cowen. At the polls, Wheeler received 3,300 votes to Swimmer's 2,437, but on the strength of a large absentee vote, Swimmer came back to win the election by fewer than 500 votes. The race was so close that Wheeler and Cowen demanded a recount and filed cases in both the Cherokee Judicial Appeals Tribunal and the U.S. district court, alleging that the Freedmen had been kept from voting because they were Wheeler party allies (Sturm 2002, 183). In fact, Wheeler and Cowen had actively campaigned in Cherokee Freedmen communities. Yet when Freedmen turned up at the polls to cast their votes during the election, they were turned away, because the Cherokee Tribal Council had recently passed $11 \mathrm{CNCA} \S 12$, the amendment formally linking Cherokee citizenship to Cherokee blood. Many Cherokees, both Freedmen and not, found the timing of that decision suspicious, as Wheeler and Cowen alleged in the courts. Not surprisingly, then, the timing of the petition for the special election in 2006 was viewed in a similar light.

Suspicions were also raised outside Cherokee country as the national news media covered the results of the special election. Most of these news stories sided with the Cherokee Freedmen and even described the outcome of the special election as a form of "ethnic cleansing" in which black Cherokee citizens had been ousted from the tribe (Lee-St. John 2007; Watson 2007). Many journalists pointed to the apparent irony of American Indians, themselves long subjected to racial discrimination, now discriminating against others. As a far-flung array of individuals and groups rallied to support the Cherokee Freedmen and to denounce the actions of the Cherokee Nation, several members of Congress got involved, including the African American congresswoman Diane Watson (D-California). 
Watson, representing a diverse district in Los Angeles County, became one the Freedmen's most vocal and prominent advocates. As soon as the results of the special election were in, she persuaded twenty-six of her fellow members in the Congressional Black Caucus to send a letter to the assistant secretary of the Bureau of Indian Affairs, questioning "the validity, legality, as well as the morality" of the special election (Evans 2007).

Even more significantly, only a few days before the Cherokee National election for principal chief, on June 21, 2007, she introduced a bill in the House of Representatives (HR 2824) proposing to "sever United States government relations with the Cherokee Nation of Oklahoma until such time as the Cherokee Nation of Oklahoma restores full tribal citizenship to the Cherokee Freedmen disenfranchised in the March 3, 2007 Cherokee Nation vote and fulfills all its treaty obligations with the Government of the United States.” If approved, the bill would have also prevented the Cherokee Nation from receiving federal funding, amounting to nearly seventy-five percent of its $\$ 300$ million annual budget, and would have suspended the tribe's authority to conduct gaming, one of the few sources of revenue that might have offset its federal losses (Hales 2007). If Watson and the Congressional Black Caucus wanted to send a clear message to the Cherokee Nation about its treatment of the Freedmen, they succeeded.

The bill created an atmosphere of grave concern among Cherokee citizens and other American Indians around the country (Barbery 2013). Many of them viewed it as yet another attempt at termination and felt that the Congressional Black Caucus had overstepped its boundaries in suggesting such a draconian measure. For example, the National Congress of American Indians (NCAI), realizing the dangerous precedent that such legislation might set, condemned the bill and defended the Cherokee Nation's decision in the name of tribal sovereignty. The NCAI viewed HR 2824 as yet another abuse of plenary power, referring to Congress's ability to override tribal sovereignty in the name of collective national rights - or in this case the civil rights of a certain class of U.S. citizens who also happened to be tribal citizens. The Cherokee Freedmen also faced accusations of directly undermining tribal sovereignty because they had invited congressional oversight into tribal matters. Although this interpretation has circulated widely throughout much of Indian Country, Cherokee Freedmen did not approach members of Congress with claims of racial discrimination. Rather, it was individuals working in Congresswoman Watson's office who first contacted Cherokee Freedmen leaders to offer their support. ${ }^{5}$ Once approached, the Cherokee Freedmen did collaborate with Watson and the Congressional Black Caucus, encouraging 
them to pressure the Cherokee Nation with HR 2824, which was referred to the House Natural Resources and Judiciary Committees in 2008. Though the resolution did not make it into law in the 110 th Congress, Watson reintroduced the bill as HR 2761 in June 2009 and continues to call for federal sanctions against the Cherokee Nation.

On the national stage, the public outcry condemning the Cherokee Nation's actions possibly trumped the significance of the potential termination legislation. In numerous media outlets, people described the Cherokee Nation's decision as "racist," although the critique itself often manifested in a racialized discourse that almost never mentioned sovereignty. Many claimed that because Cherokee people were not fulfilling noble stereotypes but instead "acting white" — as if racism were the sole province of whiteness - they no longer deserved recognition as an American Indian tribe. For example, a few days after the special election, on March 6, 2007, a blogger named Ann posted a comment regarding the Cherokee Freedmen controversy on the blog Rachel's Tavern: "Since the white Indians have spoken and have shown their love of the most hated ways of the white race, they might as well go over completely to the white race, proclaim themselves white, and get it over with." And in response to an editorial in the Muskogee Phoenix, "K" posted a comment online stating, "If the [Cherokee] government is so evil, I say eliminate the estimated 300 million dollars in federal funding the Cherokee Nation gladly accepts each year. No more of my tax dollars for this nonsense!! The Cherokee Aryan Nation needs to fend for themselves just like any other AMERICAN CITIZEN" (Muskogee Phoenix 2007).

Each of these examples, and hundreds of others like them, reflect what Byrd (2011, 37) has described as a moment in which "calls for sovereignty by the Cherokee Nation are heard by the colonizing nation and its citizens as the mimesis of white Southern demands for states' rights that immorally justified Jim Crow segregationist policies." We can go so far as to say that non-Indian outsiders read the exercise of tribal sovereignty at the heart of the tribe's efforts to determine its own citizenship standards as something akin to Governor George Wallace's defiant stand at the Little Rock schoolhouse. Though I agree with Byrd's interpretation, I want to push it further to explore how accusations of racism are used as a stand-in for indigenous assimilation and inauthenticity. In fact, these same examples make clear that indigenous people within liberal, multicultural states must fulfill nearly impossible expectations of cultural authenticity to maintain their political recognition (Barker 2005, 17). These conditions appear to provide for tribal people's empowerment, but they also serve to maintain asymmetry 
because indigenous people must continuously measure up to external expectations of authenticity, be they cultural, social, political, or something else (Barker 2011, 34-35). It follows that when Cherokees are viewed as acting racist, something not associated with authentic Cherokee culture but rather with southern white culture, they are quickly condemned as not being indigenous enough to merit political recognition.

In response to these criticisms and concerns, Cherokee citizens worried about their national reputation and what might happen if HR 2824 were passed and the tribe lost its federal funding and recognition (Barbery 2013). Stepping up its own propaganda campaign, the Cherokee Nation issued a series of glossy flyers and paid advertisements picturing the Cherokee Nation as a liberal, multicultural nation. In one example that was handed out at the Cherokee National Holiday, the words "We Are Cherokee" appear prominently at the top of the page, followed by twelve head shots of Cherokee Nation citizens, including, in the words of the flyer, two "Cherokee-Mexicans," two "Cherokee Fullbloods," a "CherokeeEcuadorian,” a “Cherokee-German," a "Cherokee-Irish,” and three "CherokeeAfrican Americans." At the bottom, the brochure defends the outcome of the special election, stating, "Cherokee citizens have voted that the Cherokee nation should be an inclusive Indian nation, allowing anyone with an Indian ancestor listed on the base rolls of the Cherokee Nation to be a citizen." The flyer reframes an act of exclusion as inclusion, implicitly celebrating the new restrictions on Cherokee citizenship as the Cherokee Nation's greatest virtue. Bringing to mind "We the People" as it appears in the preamble to the U.S. Constitution, the flyer portrays the Cherokee Nation as an inclusive, liberal, multicultural polity, no different from the United States, except in asserting its right to be "Indian."

In the summer of 2007, the Cherokee Nation also paid for thick brochures challenging HR 2824 that were handed out at the Cherokee National Holiday and in the halls of Congress. The front cover featured a photo of a young, seriouslooking Cherokee boy staring directly at the camera. The heading asks, "If Cherokee funding is cut, who will feel the pain?" The following twenty-eight pages spell out the Cherokee Nation's answers to that question - cutting funds will hurt Cherokees of all races, strand the most needy, erase the tribe's culture and traditions, leave families in need abandoned, keep their brightest from fulfilling their full potential, close the doors on young minds, leave the critically ill dying for treatment, deny health care to those in need, and keep food from the elderly (Cherokee Nation 2007b, 4-26). Each page depicts a face with a name, offering a story to bring home a carefully crafted point. The brochure denounces HR 2824 
as a punitive measure concerning the new status of Freedmen descendants, who are repeatedly described as "non-Indians" and as people who "lack documentable proof of Indian ancestry" (1-4). Again, the rhetorical move equates Cherokee citizenship with race - in this case with having Indian ancestry - and defines indigenous identity strictly in terms of lineal descent, at the expense of other possible measures. Nowhere is there mention of the abrogation of tribal citizenship established by treaty rights.

Given the political controversy that was swirling in the Cherokee Nation, tensions mounted as the general elections approached in the late spring of 2007. Voters worried that if they endorsed one candidate for principal chief over another, it would have dire consequences for the nation's political standing and possibly its federal recognition. Some believed that voting for Leeds, the challenger, would signal their support for reconsidering the predicament of the Cherokee Freedmen - a position that might be viewed as more reasonable in the eyes of Congress and the broader American public. Others feared that if Smith were not reelected, the Cherokee Nation would lose ground concerning its own sovereignty by losing the right to determine its citizenship in any way it deemed necessary. Despite these concerns, on June 23, 2007, the Cherokee people reelected Chief Smith by a large margin, with Leeds receiving only 5,675 votes to Smith's 8,035. The loss weighed heavily on Cherokee Freedmen descendants and their supporters. Rejected by their fellow Cherokee citizens in the special election and now, by implication, in the general election, they were running out of options.

One remaining hope was for a fair hearing in the Cherokee courts. Though the Freedmen immediately pressed their case, it would take another four years before the courts ruled on the legitimacy of the special election. In the intervening years, the Cherokee Freedmen controversy continued unabated, with the Freedmen seeming to alternate between partial victories and painful setbacks. However, on January 14, 2011, Judge John Cripps of the Cherokee Nation's District Court finally overturned the special election, declaring it unconstitutional and reinstating the Cherokee Freedmen as citizens (Raymond Nash, et al v. Cherokee Nation Registrar). As a result of the ruling, Freedmen descendants were able to participate in the following tribal election, a contest for principal chief between the incumbent Smith and a longtime tribal councilman, Bill John Baker. With each side representing a radically different stance on the Freedmen issue, the vote was so close that the tribal election committee could not certify a final tally, and an additional run-off election was scheduled for September 24, 2011. Yet a dramatic reversal 
of the Cherokee courts took place a month before the run-off election. On August 21, 2011, the Cherokee Nation Supreme Court vacated the recent ruling of the Cherokee District Court, effectively terminating Freedmen citizenship yet again, including their right to vote.

The Cherokee Nation Supreme Court apparently did not anticipate how this 2011 decision against the Freedmen would be received in the court of public opinion. Many observers, including a fair share of tribal insiders, interpreted the court's reversal as a blatant effort to disenfranchise Freedmen voters who nearly all supported Baker and whose numbers would likely prove decisive in determining the next principal chief. Larry Echo Hawk, the assistant secretary for Indian affairs, immediately fired off a letter to Joe Crittenden, the acting principal chief of the Cherokee Nation, saying that the Department of the Interior had never approved the constitutional amendment removing Freedmen from the tribe and that the run-off election would be considered unconstitutional if the Freedmen were prevented from voting. Soon after, the U.S. Department of Housing and Urban Development suspended 33 million dollars of funding to the tribe. Feeling pressured by the federal government's reactions, the tribe agreed to temporarily reinstate the Freedmen as citizens, so that they could vote in the run-off election, until the courts could reach a final judicial decision. As of this writing, Baker serves as the current chief of the Cherokee Nation, and the Freedmen are suing him in federal court because their rights to citizenship remain undecided. Some observers, particularly those in the field of American Indian law, believe that the Freedmen case may eventually have a hearing in the U.S. Supreme Court, which could have a major impact on legal interpretations of tribal sovereignty.

\section{INTERSECTIONS OF RACE AND SOVEREIGNTY IN CHEROKEE NATIONAL POLITICS AND BEYOND}

Though the Freedmen story is still unfolding, what can we learn from those conflicting articulations of race and sovereignty that took place in the Cherokee Nation in the years surrounding the special election? Some scholars and activists are quick to assert that indigenous identity and the sovereign rights attaching to that identity have nothing to do with race, but the case of the Cherokee Freedmen reveals a more complicated picture. First, let me make clear what I mean by sovereignty in this instance. Sovereignty signifies different things to different people, but it almost always refers to political autonomy and rights of self-determination. Yet many American Indians articulate a far more complex and even contradictory version of sovereignty. On the one hand, they describe an inherent 
form of sovereignty that coheres to them as autonomous, self-governing peoples akin to nations, one that continues to exist even when external entities fail to recognize them as such. On the other hand, they also describe a more interdependent form of sovereignty that stems from their government-to-government relationship with the United States (Sturm 2011, 151-52). As the anthropologist Jessica Cattelino (2008, 162-65) has pointed out, this second iteration of sovereignty requires astute political negotiation, economic reciprocity, and relations of interdependence with external powers. It also depends on various forms of external and internal recognition between federal, state, and tribal governments, as well as among tribal citizens themselves. Herein lies the paradox of tribal sovereignty in the contemporary context: it is a form of political independence conditioned by interdependency, one in which rhetorical purity comingles with messy realpolitik. Tribal sovereignty, then, is so highly influenced by broader social and political forces that it cannot be innocent of racial dynamics, no matter what its most rigid defenders might suggest.

Let me return to the story of the Cherokee Freedmen controversy to make my case. If Cherokee national sovereignty is defined primarily in political termsas a unique status with an accompanying bundle of rights tied to specific lands, historical experiences, and laws - then it should not matter if Cherokees look, sound, and act like popular conceptions of non-Indians. Yet reality is infused with all sorts of unruly passions and inconvenient ideas, and if we carefully examine the case of the Cherokee Freedmen during this period, we can see how racial dynamics at three different levels of interaction affected the Cherokee Nation's attempts to exercise its sovereignty. ${ }^{7}$ The first level took place between the Cherokee Nation and outsiders: as soon as Cherokees voted to disenfranchise the majority of their black citizens, many outsiders perceived them as "racists" who were "acting white" and no longer authentically Indian enough to deserve federal funding as a tribe. This was the very moment when the Congressional Black Caucus intervened, challenging the Cherokee Nation's sovereignty and threatening to cut its federal funding and recognition.

The second level of interaction took place between the Cherokee National leadership and its own citizenry. Following the 2006 Cherokee Nation Supreme Court decision regarding the Freedmen, the principal chief made the case that self-determination constituted the most basic attribute of sovereignty and that Cherokee people should decide their own citizenship standards. The chief then used the power of his office to circulate what some considered to be anti-Freedmen propaganda and to focus the vote around the question of whether the tribe 
had the right to remain "Indian." Tribal media outlets repeatedly described the Freedmen as "non-Indian" interlopers. Tribal media never addressed whether the Freedmen had lineal ties to Cherokees and were therefore kin, whether they shared in other forms of Cherokee sociality, or whether they had explicit political and legal rights to citizenship according to Cherokee law or treaties. Rather, the vote represented an effort to link Cherokee citizenship to racial distinctivenessto an explicitly Indian rather than Cherokee identity.

The third example took place among the Cherokee Nation citizenry as a whole. Because of ongoing forms of historical amnesia, many Cherokee citizens expressed confusion about the history and legal status of the Cherokee Freedmen. This collective lack of knowledge about a crucial issue placed Cherokee citizens in a vulnerable position. Seemingly few were able to see the Freedmen as fellow Cherokees, as both kin and long-term parties to the nation. The Freedmen's perceived blackness - what some have called the ocular component of race-was so supersaturated that it eclipsed their other forms of tribal belonging. When the subtle but sustained anti-Freedmen rhetoric of the tribal government combined with even nastier propaganda from individual citizens, the Freedmen were painted into a racialized corner outside the bounds of tribal recognition and sovereignty.

All these examples - at the federal, tribal, and local levels - demonstrate how racial expectations and assumptions fundamentally shaped, and even delimited, the Cherokee Nation's ability to exercise its sovereignty. Such intersections between race and sovereignty should not be surprising, given that sovereignty is a specific discursive response to living under conditions of settler colonialism, a racialized project to its core. Though still a contested concept, settler colonialism usually describes a specifically Western European form of imperialist expansion that includes Canadian, U.S., and Australian versions as well. What distinguishes settler colonialism from franchise colonialism is that the key natural resource to be extracted is indigenous land. Indigenous people can be used as a labor pool during the process of occupation and land dispossession, but the assumption is that they and their polities must eventually disappear. Moreover, as Patrick Wolfe (1999) has argued, once settlers claim indigenous lands as their own, they are here to stay. Settler colonialism is not some event that happened in the past, at a moment of invasion now over; rather, it constitutes an ongoing structural relationship in which settlers actively maintain forms of domination that enable them to continue to occupy indigenous territories in perpetuity. That oppressive relationship is justified via racialization, so that American Indian political collec- 
tives (meaning tribes as nations) are made to seem inferior to and "less civilized" than Western European nations.

Settler colonialism has quickly become one of the key analytics in the field of Native American studies, in large part because it centers indigenous political subjectivity in an ongoing struggle for power and territory. Yet the model can also prove fairly divisive in racial terms because it appears to pit indigenous people against all others. The theory suggests that even though settler colonialism is justified by a possessive investment in whiteness, and most settlers are assumed to be of Western European origin, more recent immigrants of color can take advantage of the opening of indigenous lands and become settlers too. Even African Americans, whose ancestors were brought to American shores in shackles, are seen as part of the problem because their presence was imposed on indigenous people when the settler state used their labor to help achieve its economic and military conquest. Settler colonialism does not encourage us to see the common ground of African American and Native American experience. Both peoples suffered land dispossession as they were incorporated against their will into the emerging U.S. nation-state; neither group initially had rights of citizenship within it; and the forms of citizenship eventually gained by both parties, at different times and by different means, have always remained partial and highly contested. The analytic limits of settler colonialism become even more apparent when applied to the Cherokee Freedmen whose African forebears were brought to the Cherokee Nation not by outsiders but by Cherokee slave traders and slave owners, and to those whose Cherokee ancestors may have been relatives by choice or as a result of sexual violence made possible by slavery. In this case, the settlerindigenous distinction does not prove useful for thinking through how indigenous people might mimic colonial forms of oppression and what specific indigenous identities and experiences might arise when we include the historical legacy of slaveholding in the mix.

These kinds of oversights will continue to happen as long as scholars working within Indian Country ignore the extent to which our key analytics intersect with race. Obviously, the categories of "settler" and "indigenous" are both associated with certain racial expectations, specific forms of historical experience, and different degrees of social and political empowerment. In the same way sovereignty is linked to race because it names a desire for political recognition and autonomy articulated against settler colonialism, which is an inherently racial project with ongoing racial effects. ${ }^{8}$ When we as scholars uphold the idea that sovereignty is political rather than racial, and that therefore our analytics regarding sovereignty 
need not attend to race, not only do we "divert attention away from racial theory in the field" but we actually do American Indian communities a disservice (Klopotek 2011, 7). In fact, we obscure the highly racialized power dynamics that have a real-world impact on American Indian lives. As Brian Klopotek (2011, 268) has suggested, if both colonialism and racism "emanate from a singular ideology of white supremacy, then the struggle for indigenous sovereignty has to be a struggle against racism in all its forms as well." Moreover, I want to suggest that in positioning civil rights as something separate from, or even against, tribal sovereignty, we obscure the fact that in the lived experience of people like the Cherokee Freedmen, both claims exist side by side and actually depend on one another. For Freedmen descendants, Indianness and Cherokee citizenship are sites of shared identification with other Cherokees and a place from which they, too, claim rights to sovereignty (Byrd 2011, 38). We need to be more attentive to the ways in which race troubles forms of sovereignty based on mutual recognition, including how accusations of racism within tribal politics invite federal interference and can set alarming new legal precedents for tribal people throughout the country. Only then can we understand the actual complexity of racial dynamics within indigenous communities, and only then will our work empower tribes to act as moral sovereigns committed to protecting the civil rights of their own citizenry.

\section{ABSTRACT}

Despite a treaty in 1866 between the Cherokee Nation and the federal government granting them full tribal citizenship, Cherokee Freedmen - the descendants of African American slaves to the Cherokee, as well as of children born from unions between African Americans and Cherokee tribal members - continue to be one of the most marginalized communities within Indian Country. Any time Freedmen have sought the full rights and benefits given other Cherokee citizens, they have encountered intense opposition, including a 2007 vote that effectively ousted them from the tribe. The debates surrounding this recent decision provide an excellent case study for exploring the intersections of race and sovereignty. In this article, I use the most recent Cherokee Freedmen controversy to examine how racial discourse both empowers and diminishes tribal sovereignty, and what happens in settler-colonial contexts when the exercise of tribal rights comes into conflict with civil rights. I also explore how settler colonialism as an analytic can obscure the racialized power dynamics that undermine Freedmen claims to an indigenous identity and tribal citizenship. [Native North America; Cherokee Freedmen; race; sovereignty; settler colonialism; citizenship] 


\section{NOTES}

Acknowledgments This article has greatly benefited from the insightful feedback I received on earlier drafts from Edmund Gordon, J. Kehaulani Kauanui, Randolph Lewis, Celia Naylor, Pauline Turner Strong, Kimberly TallBear, and Shirley Thompson. I also received helpful comments from graduate students in my "Politics and Conditions of Indigeneity" seminar in the fall of 2012 at the University of Texas at Austin, and I specifically thank Andrew Uzendoski who argued convincingly that in criticizing a nation for its responsibilities to its own citizens, I would be reinforcing it as a sovereign. My deep appreciation also goes to the three Cherokee women who stood with me during my presentation at the 2011 Native American and Indigenous Studies Association meeting in Connecticut and who urged me to take a more public stand on the Freedmen issue. Though I am immensely grateful to all of you for your wisdom and support, I alone am responsible for the contents of this article.

1. Though most Cherokee Freedmen have predominantly African and African American ancestry, some also have Cherokee ancestors. The percentage of Cherokee Freedmen with Cherokee ancestry is a matter of debate, with estimates ranging from one-tenth to one-third (Cooper 2011). Here, I describe the enslaved ancestors of Cherokee Freedmen as African Cherokees not to suggest that all Freedmen have Cherokee ancestry but to highlight their Cherokee national ties.

2. Certificate Degrees of Indian Blood are issued by the Bureau of Indian Affairs to certify and quantify an individual applicant's American Indian ancestry, often using state-certified vital records. They provide a degree of ancestry by tribe, such as " $1 / 4$ Choctaw and $1 / 8$ Cherokee." Important to note is that CDIBs are not evidence of tribal citizenship; individuals can have a CDIB and still not meet the standards for enrollment set by tribal governments. The opposite holds true as well: individuals like the Cherokee Freedmen may qualify for tribal citizenship, even if they do not possess a CDIB.

3. Although most of my examples are drawn from public records and news media sources, my interpretations are informed by nearly fourteen years of both formal and informal fieldwork that took place between 1995 and 2009, when I lived in Oklahoma less than three hours by car from the Cherokee Nation proper. During this period, I had close working relationships with community members and political leaders both in the Cherokee Nation and in the Descendants of the Freedmen of the Five Civilized Tribes Association.

4. At the time, the homepage of the Cherokee Nation's official website had a prominent link on the right-hand side titled, "Freedmen Press Kit: Questions about the Citizenship Status of Non- Indians" (Cherokee Nation 2007a). The press kit, while it meant to inform Cherokee citizen voters about the history and political standing of the Cherokee Freedmen, immediately biased less informed readers.

5. Personal interview with staffer in Congresswoman Watson's office, Washington, D.C., November 30, 2007.

6. The Rachel's Tavern blog is no longer accessible online. However, Ann has her own blog, Beautiful, Also, Are the Souls of My Black Sisters, where she has commented extensively on the Cherokee Freedmen controversy and has reposted her original comments from Rachel's Tavern. See "The Freedmen/Women and the Cherokee Nation: Part 2," Beautiful, Also, Are the Souls of My Black Sisters blog, July 26, 2008, http://kathman duk2.wordpress.com/2008/07/26/the-freedmenwomen-and-the-cherokee-nationpart-2.

7. Note that because the Cherokee Nation does not determine tribal citizenship on the basis of blood quantum (a more obviously racialized measure of belonging), as do many tribes throughout the United States, but rather on lineal descent (a primarily genealogical or kinship- based measure), the intersections of race and sovereignty are all the more significant here.

8. As theorists like Antonio Gramsci and Pierre Bourdieu have made clear, counterhegemonic narratives tend to unconsciously reproduce some of the ideological aspects they 
explicitly resist. So, discourses of sovereignty will likely reproduce some of the racial assumptions inherent in the settler-colonial project, as we have seen here.

\section{REFERENCES}

Barbery, Marcos

2013 "From One Fire." This Land Magazine, May 16. http://thislandpress.com/05/ 16/2013/from-one-fire/, accessed September 21, 2013.

Barker, Joanne

2005 Sovereignty Matters: Locations of Contestation and Possibility in Indigenous Struggles for Self-Determination. Lincoln: University of Nebraska Press.

2011 Native Acts: Law, Recognition and Cultural Authenticity. Durham, N.C.: Duke Byrd, Jodi A. University Press.

2011 “'Been to the Nation, Lord, But I Couldn't Stay There': American Indian Sovereignty, Cherokee Freedmen, and the Incommensurability of the Internal.” Interventions 13, no. 1: 31-52. http://dx.doi.org/10.1080/1369801X.2011. 545576.

Cattelino, Jessica

2008 High Stakes: Florida Seminole Gaming and Sovereignty. Durham, N.C.: Duke University Press.

Cherokee Nation

2007a "Freedmen Press Kit: Questions about the Citizenship Status of Non-Indians." Cherokee Nation website. http://www.cherokee.org, accessed October 22, 2008.

Cherokee Nation

2007b “If Cherokee Funding is Cut, Who Will Feel the Pain?" Brochure.

Cooper, Kenneth J.

2011 "Citizenship Deferred: Descendants of Cherokee Slaves are Still Fighting for Voting Rights and Basic Services.” Diverse Issues in Higher Education 28, no. 21: $12-13$.

Evans, Ben

2007 “Black Caucus Questions Cherokee Vote.” Associated Press, March 13.

Feldhousen-Giles, Kristy

2008 “To Prove Who You Are': Freedmen Identities in Oklahoma.” PhD dissertation. University of Oklahoma.

Hales, Donna

2007 “Group Questions Cherokee Vote to Oust Freedmen.” Muskogee Phoenix, March 16. http://www.muskogeephoenix.com/local/x2128958093/Group-questionsCherokee-vote-to-oust-freedmen, accessed May 23, 2014.

Kauanui, J. Kehaulani

2008 "Colonialism in Equality: Hawaiian Sovereignty and the Question of U.S. Civil Rights." South Atlantic Quarterly 107, no. 4: 635-50. http://dx.doi.org/10. 1215/00382876-2008-010.

Ketcher, John

2007 "Vote Yes on the Constitutional Amendment Determining Citizenship in the Cherokee Nation.” Cherokee Phoenix, February. http://www.cherokeephoenix. Klopotek, Brian org/uploads/2007/2/463_2007-02-01.pdf, accessed September 1, 2013.

2011 Recognition Odysseys: Indigeneity, Race and Federal Tribal Recognition Policy in Three Louisiana Communities. Durham, N.C.: Duke University Press.

Knickmeyer, Ellen

2007 “Cherokee Nation to Vote on Expelling Slaves' Descendants." Washington Post, March 3, A1.

Lee-St. John, Jeninne

2007 “The Cherokee Nation's New Battle.” Time Magazine online, June 21. http:// 
http://content.time.com/time/nation/article/0,8599,1635873,00.html, accessed June 28, 2007.

Muskogee Phoenix

2007 “Rep. Delays Cherokee Cuts." Editorial, Muskogee Phoenix, September 15. http://muskogeephoenix.com/editorials/x2128972743/Rep-delays-Cherokeecuts, accessed October 10, 2007.

Rolnick, Addie C.

2011 “The Promise of Mancari: Indian Political Rights as Racial Remedy." 86 New York University Law Review 958:101-83.

Ruckman, S. E.

2007 "Freedmen Supporters Picket BIA: The Group Says Agency Must Uphold Rights Guaranteed by a Treaty." Tulsa World, April 7.

Russell, Steve

2011 “Tsunami Warning From the Cherokee Nation." Indian Country Today, September 14. http://indiancountrytodaymedianetwork.com/opinion/tsunami-warning-

Smith, Chadwick from-the-cherokee-nation-54005, accessed September 26, 2011.

2006 “Citizen Views Fall on Both Sides of Freedmen Issue." Cherokee Phoenix, April: 33.

Strong, Pauline Turner

2005 "What is an Indian Family? The Indian Child Welfare Act and the Renascence of Tribal Sovereignty." In "Indigenous Peoples of the United States," special joint issue of American Studies 46, nos. 3-4, and Indigenous Studies Today 1:205-31.

Sturm, Circe

2002 Blood Politics: Race, Culture, and Identity in the Cherokee Nation of Oklahoma. Berkeley: University of California Press.

2011 Becoming Indian: The Struggle over Cherokee Identity in the Twenty-first Century. Santa Fe, N.M.: School for Advanced Research Press.

Vann, Marilyn

2006a “The Cherokee Freedmen Story as of May 7, 2006-Updated 529 06.” http:// www.freedmen5tribes.com/Cherokee.htm, accessed April 21, 2011.

2006b “The Cherokee Freedmen Story as of May 7, 2006.” Cherokee Observer, July 1: 4. Watson, Diane

2007 “Jim Crow in Indian Country." Huffington Post, October 25. http:// www.huffingtonpost.com/rep-diane-watson/jim-crow-in-indian-

Wilkins, David countr_b_69927.html, accessed June 30, 2008.

2001 American Indian Politics and the American Political System. New York: Rowman and Littlefield.

Wolfe, Patrick

1999 Settler Colonialism and the Transformation of Anthropology: The Politics and Poetics of an Ethnographic Event. London: Cassell. 